\title{
The Special Collections in the Peace Palace Library and the work of Library Director Dr Jacob ter Meulen
}

This paper was originally presented under the title, "The Peace Palace Library. Its collections: historic and those serving the objective of contemporary arbitration and adjudication. Its users: courts, academics and the general public" at the Socio-Legal Sources and Methods in International Law workshop, held at the Institute of Advanced Legal Studies in London on November $25^{\text {th }}, 2016$.

Since the 1924-1952 Peace Palace Library Director Dr Jacob ter Meulen played such a crucial role in the shaping of the Special Collections about which the above mentioned lecture was centered the text and form of everything hereunder focuses extensively on $\mathrm{Dr}$ Jacob ter Meulen. Moreover, it is worth addressing the life and work of Dr Jacob ter Meulen because he has not received much scholarly attention in easily available publications such as Legal Information Management ${ }^{1}$.

\section{General Introduction on the Aims and Collections of the Peace Palace Library}

Andrew Carnegie, a passionate pacifist (he was a firm believer in the idea of 'Peace Through Justice') and a champion of libraries (because documentation was educationally quintessential for acquiring knowledge to avert war and achieve peace), donated $\$ 1.5$ million in 1903-4 for the construction of his strongly desired Temple of Peace, -being a Court House, housing the Permanent Court of Arbitration established at the First Hague Peace Conference of 1899, and the Peace Palace Library (or Carnegie Library as it was sometimes called)-, which was formally and ceremonially inaugurated in 1913 as the Peace Palace.

In this manner Andrew Carnegie (1835-1919) contributed to the establishment of the phenomenon of The Hague as, "The Legal Capital of the World" or the "Le capital juridique du monde" after Boutros Boutros Ghali's 1990's words. This concept was swiftly embraced by Wim Deetman, Mayor of the City of The Hague, promoting the international status of the municipality and utilizing the Peace Palace as the most persuasive symbol to emphasize the goals of 'Peace, Justice and Security'. Contributing further to this concept, even before any building activity for the Peace Palace had started, in 1905 K.P.C. de Bazel had designed an internationalist (i.e. pacifist) city plan for The Hague.

Still, Andrew Carnegie as promotor of the concept of 'The Hague as the Legal Capital of the World' complemented the work of the nineteenth century Dutch international legal diplomat Tobias Asser (1838-1913), who was Professor of International Commercial Law, founder of the Hague Conference on Private International Law (1893) and contributor to the formation of the Permanent Court of Arbitration at the First Hague Peace Conference of 1899. And Andrew Carnegie similarly complemented the activities of Austrian baroness Bertha von Suttner (1843-1914), who authored the novel "Die Waffen nieder!" ("Lay Down Your Arms") -

\footnotetext{
${ }^{1 *}$ Diermanse, P.J.J., Jacob ter Meulen, in: Jaarboek van de Maatschappij der Nederlandse Letterkunde te Leiden 1962-1963, Leiden, 1963, pp. 128-133.

${ }^{*}$ From Erasmus to Tolstoy. The peace literature of four centuries. Jacob ter Meulen's bibliographies of the peace movement before 1899, edited, with an introduction by Peter van den Dungen, foreword by Arthur Eyffinger, New York, 1990.

${ }^{* * *}$ Russer, W.S., Dr. Jacob ter Meulen, in: Bibliotheekleven, Year 37, Issue 11 (November 1952), pp. 313-315.

${ }^{* * * *}$ Diermanse, P.J.J., Landheer, B., In memory of dr. Jacob ter Meulen, in: American Journal of International Law, Vol. 57, No. 2 (April 1963), pp. 391-393.
} 
a book that convinced the nineteenth century bourgeoisie about the horrors of warfare and demonstrated well what war inflicts upon a family. This seminal book eventually resulted in the establishment of a series of Peace Societies throughout Europe. Bertha von Suttner also functioned as a key confidant or private counsel for kings, statesmen, diplomats and politicians with meetings often taking place in the Kurhaus Hotel during the First and Second Hague Peace Conferences of 1899 and 1907.

Even Hugo Grotius (1583-1645), the seventeenth century Dutch founder of modern international law is advanced as another possible father of The Hague as today's city of international law. This persuasive argument is based on Grotius's seminal 1625 work "De lure Belli ac Pacis" ("On the Laws of War and Peace").

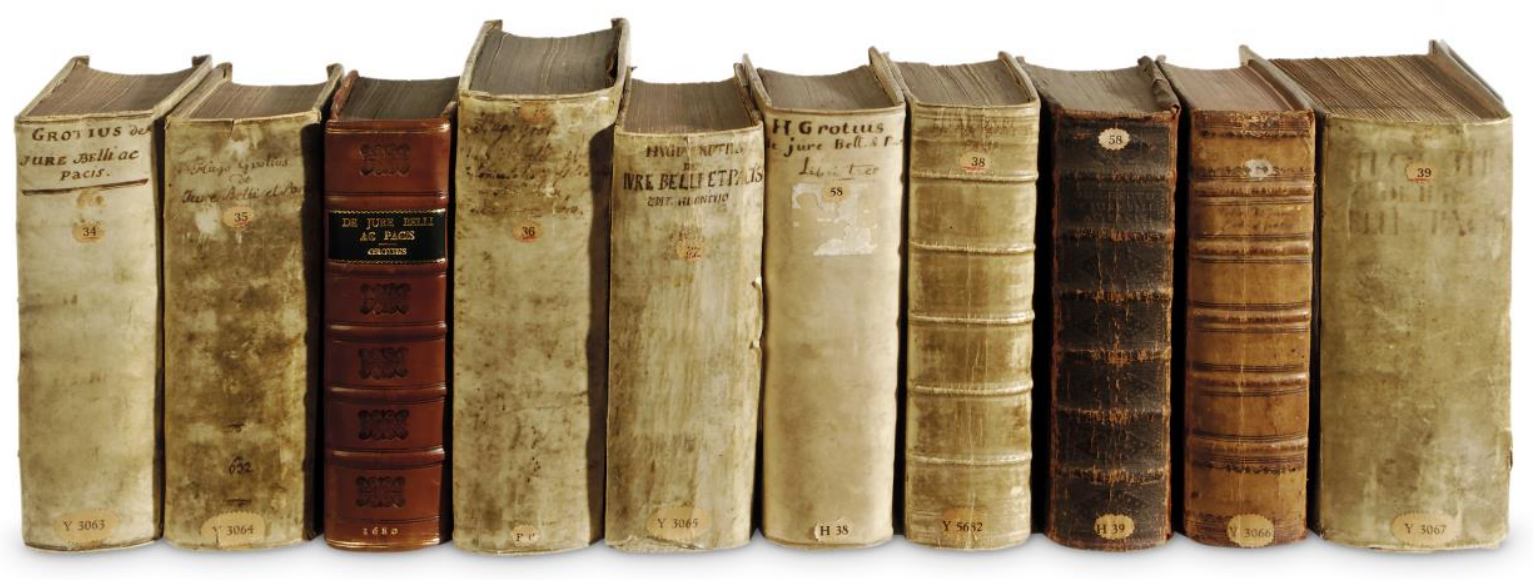

A set of editions of "De lure Belli ac Pacis"

The remaining interesting question is how the Peace Palace Library itself acted as a pivotal generator of The Hague as 'City of Peace and Justice'.

The Peace Palace Library is world-famous for its public and private international law collections. It also holds large collections on comparative law and national laws, and on diplomatic history and the history of conflict areas. Its primary institutional users are the Permanent Court of Arbitration (established in 1899) and the International Court of Justice (established in 1946, successor to the Permanent Court of International Justice, founded in 1920), both housed in the Peace Palace. Secondly other international courts and tribunals in The Hague benefit from the Peace Palace Library's collections, e.g. the International Criminal Court (established under the Rome Statute and concluded in 1998) and the 'Hoge Raad' (i.e. the Dutch Supreme Court). In addition to providing access by these courts and tribunals, the Peace Palace Library operates as the library for The Hague Academy of International Law which has offered summer courses since 1923. Finally, the Peace Palace Library is an international law library for a general readership that mostly consists of professors, scholars and research students based both inside and outside The Netherlands.

\section{Life and Work of Dr Jacob ter Meulen}

Jacob ter Meulen was born into a Mennonite family in The Hague on December 3rd, 1884. $\mathrm{He}$ was the son of François Pieter ter Meulen, a painter, famous for heathland scenery landscapes with sheep and a member of the somber impressionist realist post-Hague School. 
Jacob ter Meulen studied constitutional law and public international law and political economy at the University of Amsterdam (then the Municipal University), with the professors A.A.H. Struycken and D. van Emden. He was awarded his PhD (magna cum laude) in 1914 from the University of Zürich. His thesis concerned early ideas on a league of nations, "Beitrag zur Geschichte der Internationalen Organisation 1300-1700" and was authored under the guidance of Max Huber in Zürich. His related publication "De ontwikkeling der statengemeenschap. Historische schets" ("The Development of the Community of States. Historical Sketch") appreared in the Grotius Internationaal Jaarboek and was published in 1916. Ter Meulen had decided to undertake his university training in Zürich, since he was a pacifist and was was much under the spell of Max Huber (who had participated in the Second Hague Peace Conference of 1907).

His thesis on the development of internationalist thought, was published in an enlarged form and entitled "Der Gedanke der internationalen Organisation in seiner Entwicklung 13001800 " (ending with a section on Immanuel Kant) and appeared as the first volume of a trilogy in 1917. This trilogy was published by Martinus Nijhoff betwen 1917 and 1940. The second volume, covering the period 1789-1867 (e.g. containing information on the French socialist utopists) was published in 1929; the third volume covered 1867-1889 (culminating in chapters on International Law and International Arbitration) was published in 1940. This trilogy mirrors very much Ter Meulen's sympathy for idealist thinkers and limitless dreams about a world pacified. For Ter Meulen, as a Mennonite, war was unacceptable, he believed in peaceful resistance and stood for defencelessness (although he was willing to be militarily mobilized as a conscript in the First World War). This explains clearly the pacifist and antimilitaristic collections of the Peace Palace Library as formed by Ter Meulen (see below).

After a short career as a secondary school teacher he started at the Utrecht University Library and shaped the structure for the classification of law. Thereafter Ter Meulen became Director of the Library of the Netherlands School of Commerce, now Erasmus University Rotterdam. On January 1st, 1924 Ter Meulen started his career at the Peace Palace Library. Because of the special character of the Peace Palace Library and the international political climate Ter Meulen increasing entered anti-militarist circles and subsequently got involved in pacifism. His view was very much of a Christian anti-militarist kind, based upon the belief of the Mennonite Church in the Netherlands. Ter Meulen joined the Working Group of Mennonites against Military Service, also called the Mennonite Peace Association (Ter Meulen fulfilled many roles in international Mennonite networks). In addition to his regular work, Jacob ter Meulen was also President of the Dutch Library Association, founder and coeditor of the "Grotius Jaarboek" (1913-1948) and from 1926 onwards was a member of the Dutch Committee on International Intellectual Cooperation. Jacob ter Meulen died ten years after his retirement on August 12th, 1962. 


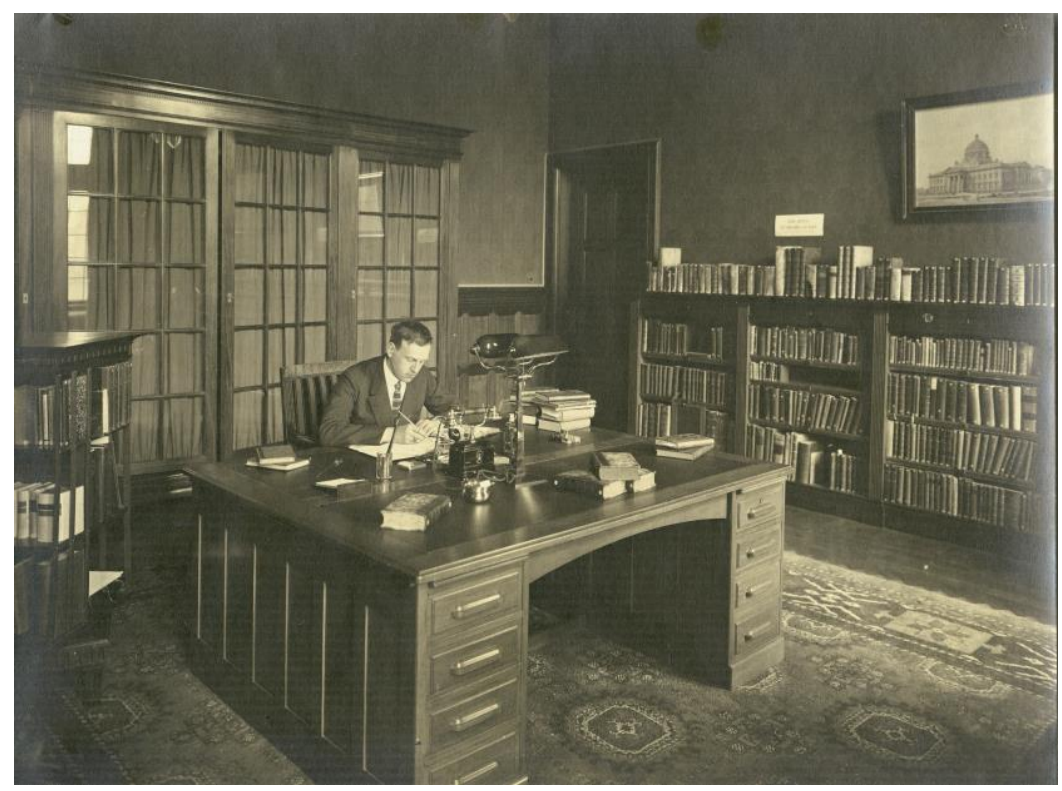

Ter Meulen working in his office surrounded by the rare books of the Hugo Grotius collection

\section{The Hugo Grotius Collection}

The Peace Palace was inaugurated on August 28th, 1913, and the Permanent Court of Arbitration moved into these new premises; a 'Standard Library of International Law' came into existence at the same time: the Peace Palace Library.

Soon after the formal opening, in 1914, Martinus Nijhoff, the bookseller in The Hague and renowned bibliographer and humanities scholar, donated his personal collection of copies of "De lure Belli ac Pacis", in various languages, to the Peace Palace Library. The Nijhoffassortment comprised 44 editions, of course in Latin (the original language of the publication), but also in French, English, German and Dutch. Imprints ranged from the entire early modern era, but amidst the donated books a 1625 'De lure Belli ac Pacis' (third press run of the first edition of 1625) was included as well (TMD 565-III; TMD is the bibliographer's manner of referring to Grotius editions, an abbreviation of 'Ter Meulen - Diermanse', standing for the canonistical compilation J. ter Meulen and P.J.J. Diermanse, "Bibliographie des écrits imprimés de Hugo Grotius", The Hague, Nijhoff, 1950, being the most comprehensive overview of titles by Hugo Grotius in various editions and with various imprints).

Ter Meulen must have felt the inaugural initial donation to the Peace Palace Library as an impetus or obligation to consistently expand the collection of Hugo Grotius' "De lure Belli ac Pacis" ("On the Laws of War and Peace"), and of other legal works of Hugo Grotius, such as "Mare Liberum" [1609] ("The Free Sea") and "Inleidinge tot de Hollandsche rechtsgeleerdheid" [1631] ("Introduction to Dutch Jurisprudence"). This all combined in Ter Meulen's achievement of the vast and unique "History of International Law Collection" which we see today at the Peace Palace Library. Additionally, Ter Meulen dedicated his efforts to expand the Hugo Grotius collection to other scholarly and artistic domains of Hugo Grotius: philology, history, theology and poetry. (All items ever published being bibliographically listed in the abovementioned TMD, i.e. J. ter Meulen and P.J.J. Diermanse, Bibliographie des écrits imprimés de Hugo Grotius. The Hague, Nijhoff, 1950.)

In short, the legal history scholar Hugo Grotius specialist Jacob ter Meulen, especially after he had prepared a book section of a exhibition in 1925 at the tricentenary of "De lure Belli ac Pacis", relentlessly worked on the expansion of the Hugo Grotius book collection in 
particular, and by doing so he built upon the first bricks laid by his predecessor Dr P.C. Molhuysen.

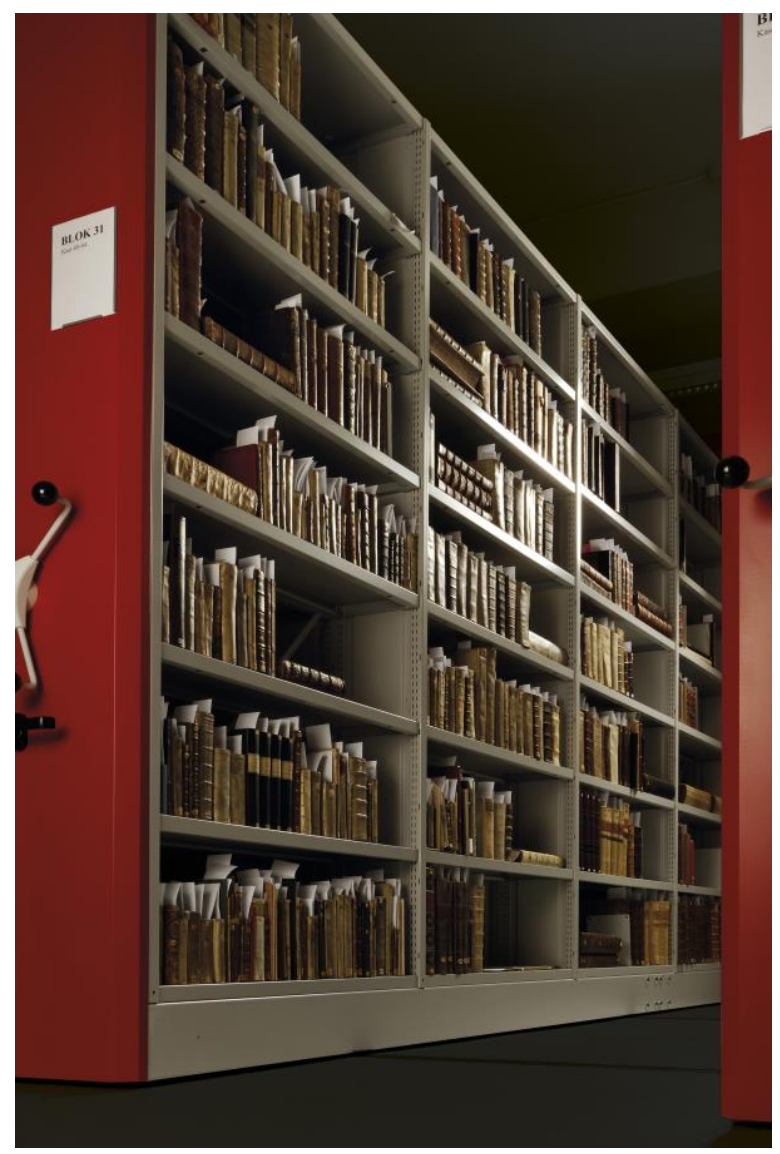

The Hugo Grotius collection in the Peace Palace Library stacks

\section{The Peace Movement Collection}

In addition to his other considerable achievements, Jacob ter Meulen is also to be remembered as a bibliographer, e.g. his work on Hugo Grotius is of seminal value. He introduced himself as a systematic classifier of law at the Utrecht University Library, and Ter Meulen has always remained a classifier and an expert on classification systems and on thesauri of subject headings. His classifying work "Catalogue de la Bibliothèque du Palais de la Paix" / "Catalogue of the Peace Palace Library" (1916-1952, 7 Vols.), printed and bound in the Bordeaux red wine volumes, are evidence of his expertise.

Equally significantly Ter Meulen developed as a bibliographer of the Peace Movement. His "Bibliography of Peace" demonstrates his skills. After Henri La Fontaine's "Bibliographie de la paix et de l'arbitrage internationale" (1903) was published at the International Institute of Peace in Monaco and the Catalogue of the Library of the Norwegian Nobel Institute (1912) in Oslo (and after the first printed catalogues of the Peace Palace Library, compiled by P.C. Molhuysen) the "Bibliography of the Peace Movement Before 1899" [1934] (covering the period 1776-1899, listing 3,500 items; a second part covering 1490-1776 was published in 1936, containing 500 items) was created by Ter Meulen, which made him, in conjunction with his bibliographic work on Hugo Grotius, the undisputed bibliographer of peace.

The Peace Movement Collection as a special collection consists of books, brochures, pamphlets, conference reports, newspaper clippings, letters and photographs from pacifist 
organizations and individuals connected with these organizations. These groups and individuals all strived for world peace in the period 1900-1940. Most of the materials are in Dutch, but there are also books and documents in English, German, French and other languages. All items in the Peace Movement Collection were added to an inventory list, published in J. Haasbeek (ed.), "Vredescollectie - Collection de dossiers relatifs du mouvement pacifiste ("Collection of dossiers concerning the Peace Movement") (1993, 1st Ed., 2011, 2nd Ed.). The records in the Peace Movement Collection, roughly 1,500 items, are now searchable in a database on the Peace Palace Library's website.

In 2004-2005 the massive digitization of the Peace Movement Collection took place through the Metamorfoze project of the 'Koninklijke Bibliotheek' (Royal Library, the National Library of the Netherlands) and all items were put on microfilm at the same time.

The Peace Palace Library commemorated the start of the First World War with a Centenary Exhibition and with a series of blogs and items on the website. The Peace Palace Library's collection on the Great War is focused on aspects of international law: the laws of war, the Paris Peace Conference, the peace treaties of 1919-1920, the war reparations and the politics of its memory. For that purpose, an extensive research guide on the topic was prepared as a starting point for research in the Peace Palace Library.

The First World War Centenary Exhibition was based on the Peace Palace Library's 'image' collection, telling the story of the First World War through posters. This 'image' collection contains engravings, posters (woodcuts, etchings, lithographs, drawings), cartoons, photographs and maps.

Together, the components of the 'image' collection form a visual supplement to the book collection. They show important historical scenes or persons. They refer to themes and subjects, which are research topics in the library. The so-called "Poster collection" particularly reflects subjects such as "Peace", "War" and "Anti-war movements". The images on the posters from World War I and World War II give vivid impressions of the horrors of war, calling for support for the war parties and the fight against fascism. As such, the 'image' collection is an integral part of the Peace Movement Collection. A selection of the often dramatic posters are below. 


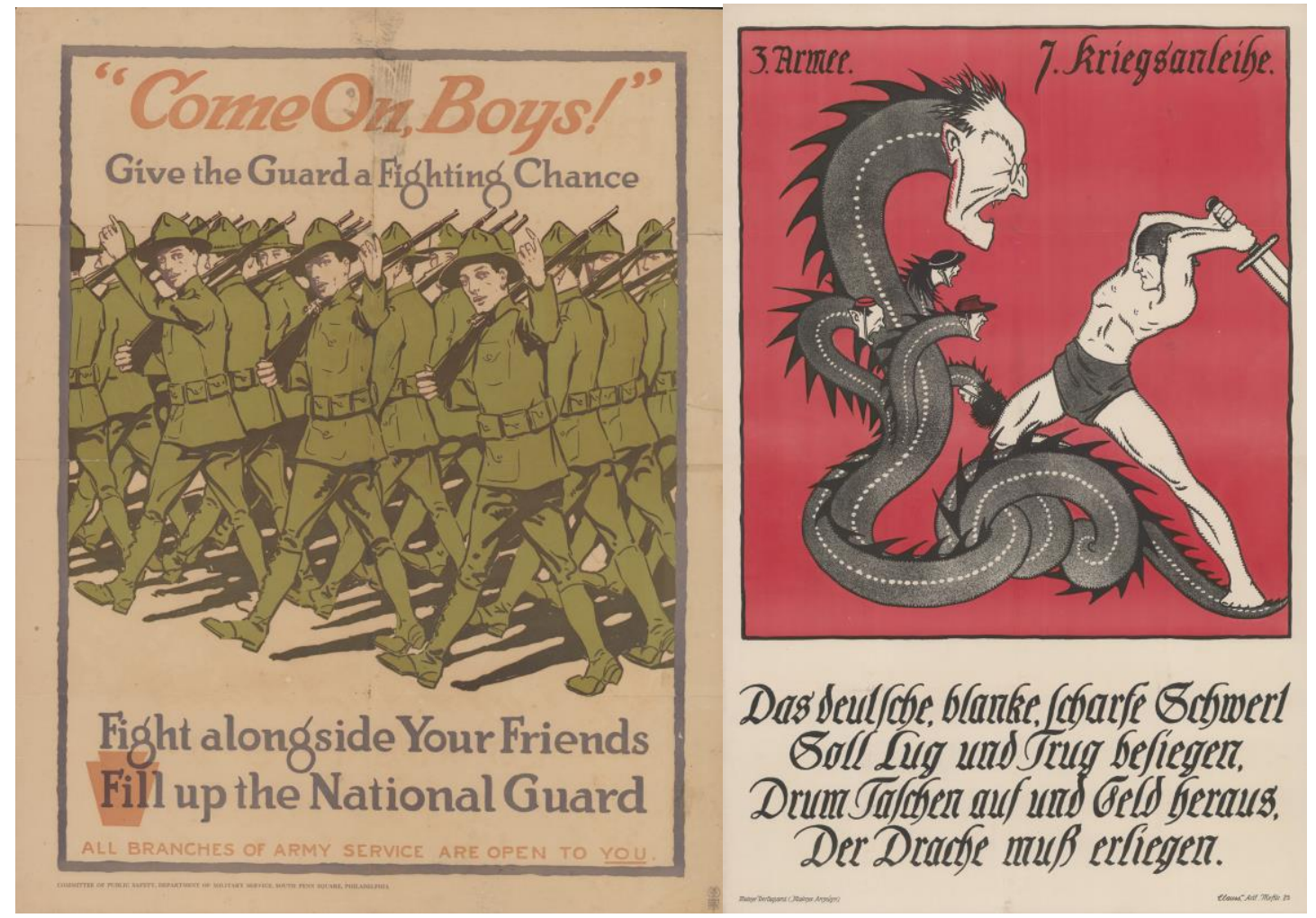

Jeroen Vervliet

Library Director

The Peace Palace, The Hague, The Netherlands

See also: www.peacepalacelibrary.nl 